\section{Dose-related changes in vaginal cytology after topical conjugated equine oestrogens}

Symptoms of ovarian failure confined to the lower genital tract are probably most sensibly treated with topical oestrogens. The optimal dosage should relieve local discomfort without causing systemic side effects. Topical oestrogens, however, are rapidly absorbed into the peripheral circulation ${ }^{1}$ and may depress gonadotrophin concentrations. ${ }^{2}$ The recommended dosage of Premarin Vaginal Cream (conjugated equine oestrogens), $1.25 \mathrm{mg}$ daily, yields plasma oestrogen concentrations almost identical with those after oral administration of that dose. ${ }^{1}$ Excessive endometrial stimulation and hyperplasia may develop. ${ }^{13}$ To determine whether a lower dose would reduce the local beneficial effects we have investigated the vaginal response to four different dosages of oestrogen cream.

\section{Patients, methods, and results}

We studied 24 patients aged 43-63 years. All had symptoms of lower genital tract atrophy and either had not menstruated spontaneously for 12 months or had menstruated but with at least three months between menses. ${ }^{4}$ None had received any medication for three months.

After assessment patients were assigned at random to one of four groups (six women in each) allocated to receive $2 \mathrm{~g}$ cream nightly for one month containing either $0.1,0.4,0.8$, or $1.25 \mathrm{mg}$ conjugated equine oestrogens. The cream was inserted with an applicator, and neither the vatients nor their attendants knew which dosage they were receiving. During treatment and for four weeks afterwards patients attended at weekly intervals. Symptoms were recorded and smears prepared from cells aspirated from the posterior fornix. Smears were fixed in shorr and haematoxylin and the oestrogen index ${ }^{4}$ measured to assess epithelial cell proliferation and maturation.

Distribution of values in each group at each time was examined by calculating the arithmetic and geometric means, standard deviation (before and after log transformation), median, and degrees of skewness and kurtosis. Data were best described by a log-normal model. Oestrogen indices were compared using Student's $t$ test on logged data.

The four groups were similar in age, menopausal state, and pretreatment oestrogen indices. With each regimen the mean oestrogen index was significantly increased after one week and the maximal response achieved after two weeks; values then declined (table).

Oestrogen indices in menopausal women before, during, and after treatment with four dosages of vaginal oestrogen cream. Figures are percentages (geometric means and ranges)

\begin{tabular}{|c|c|c|c|c|}
\hline \multirow{2}{*}{$\begin{array}{l}\text { Weeks } \\
\text { of } \\
\text { study }\end{array}$} & \multicolumn{4}{|c|}{ Dose of oestrogen cream (mg/day) } \\
\hline & $0 \cdot 1$ & $0 \cdot 4$ & $0 \cdot 8$ & $1 \cdot 25$ \\
\hline 0 & $4 \cdot 7(2-38)$ & $\begin{array}{l}\text { Before treatment } \\
3 \cdot 1(1-18)\end{array}$ & $2 \cdot 7(1-19)$ & $10 \cdot 4(2-56)$ \\
\hline $\begin{array}{l}1 \\
2 \\
3 \\
4\end{array}$ & $\begin{array}{l}27 \cdot 0(5-80)^{*} \\
29 \cdot 4(10-74)^{* *} \\
22 \cdot 3(3-80)^{*} \\
23 \cdot 8(2-78)^{*}\end{array}$ & $\begin{array}{l}\text { During treatment } \\
72 \cdot 0(52-95)^{* * *} \\
72 \cdot 5(46-88)^{* * *} \\
52 \cdot 3(36-68)^{* * *} \\
50 \cdot 2(28-66)^{* *}\end{array}$ & $\begin{array}{l}68 \cdot 0(50-90)^{* * *} \\
67 \cdot 5(54-92)^{* *} \\
56 \cdot 6(38-84)^{* * *} \\
33 \cdot 3(6-80)^{* *}\end{array}$ & $\begin{array}{l}64 \cdot 7(50-80)^{*} \\
81.5(62-94)^{*} \\
59 \cdot 6(56-72)^{*} \\
47 \cdot 0(16-90)\end{array}$ \\
\hline $\begin{array}{l}5 \\
6 \\
7 \\
8\end{array}$ & $\begin{array}{r}9 \cdot 0(6-12)^{*} \\
13 \cdot 5(9-28)^{*} \\
13 \cdot 4(5-22)^{*} \\
13 \cdot 1(1-15)^{*}\end{array}$ & $\begin{array}{l}\text { After treatment } \\
24 \cdot 5(8-42)^{*} \\
7 \cdot 0(2-14) \\
5 \cdot 3(1-21) \\
1 \cdot 2(1-2)\end{array}$ & $\begin{array}{l}28 \cdot 2(20-64)^{* *} \\
6 \cdot 8(2-30) \\
2.5(1-4) \\
1.6(1-3)\end{array}$ & $\begin{array}{c}33 \cdot 9(6-72) \\
29 \cdot 6(22-52) \\
7 \cdot 5(1-23) \\
5 \cdot 0(1-30)\end{array}$ \\
\hline
\end{tabular}

Compared with values before treatment: ${ }^{*} \mathrm{p}<0.05 ;{ }^{* *} \mathrm{p}<0.005 ;{ }^{* * *} \mathrm{p}<0.0005$.

Oestrogen indices observed in our department during the menstrual cycle are between $15 \%$ and $30 \%$, and the lowest dosage of oestrogen produced values within this range. Dosages of $0.4,0.8$, and $1.25 \mathrm{mg}$ produced higher values than normal for women of reproductive age, and there were no significant differences in values among the three higher dosages.

Oestrogen indices remained significantly above baseline throughout the four weeks of follow-up after $0.1 \mathrm{mg}$, for one week only after 0.4 and $0.8 \mathrm{mg}$, and not at all after $1.25 \mathrm{mg}$.

\section{Comment}

Despite the wide range of oestrogen indices with all four dosages of oestrogen cream, indicating interpatient variation, the minimum daily dosage to induce premenopausal values for vaginal cytology was $0.1 \mathrm{mg}$. Though the three higher dosages are necessary for the relief of hot flushes, they are unlikely to be essential for relief of vaginal symptoms since equally beneficial local effects (paper in preparation) were observed with all dosages. Thus the manufacturer's recommended dosage can be greatly reduced.

The decrease in oestrogen index during the third and fourth weeks of treatment with all regimens confirms the loss of local effect with prolonged treatment. ${ }^{1}$ There was no evidence of decreasing patient compliance. More likely was a loss of sensitivity to oestrogen within the vaginal epithelium: responsive tissues may become refractory when oestrogen stimulation lasts beyond 14 days. ${ }^{5}$ Vaginal sensitivity may be lost because of changes such as tissue cornification or because of intracellular modifications, such as down-regulation of the receptor mechanism. Whatever the explanation, the oestrogen index decreased most in the last two weeks with dosages exceeding $0.4 \mathrm{mg}$ and least with $0 \cdot 1 \mathrm{mg}$.

The duration of the beneficial "carry-over" effects apparently depended on the initial dosage. The oestrogen index returned to the pretreatment range within seven days of stopping $1.25 \mathrm{mg}$ and within 14 days of stopping 0.8 and $0.4 \mathrm{mg}$. With $0.1 \mathrm{mg}$, however, the mean values remained significantly above baseline during the four weeks of follow-up. Cellular responsiveness to oestrogen disappeared most rapidly with higher dosages, which also caused the quickest return to baseline after treatment. Failure to obtain symptomatic relief with high dosages of creams may be better managed not by further increasing the dosage but by stopping treatment for a short interval and then restarting at lower dose.

We acknowledge Ayerst Laboratories (UK) for financial help to G I Dyer and $\mathrm{P} T$ Townsend.

Requests for reprints should be sent to Dr M I Whitehead.

${ }^{1}$ Whitehead MI, Minardi J, Kitchin Y, Sharples MJ. Systemic absorption of estrogen from Premarin Vaginal Cream. In : Cooke ID, ed. The role of estrogen/progestogen in the management of the menopause. Lancaster: MTP Press Ltd, 1978:63-71.

${ }^{2}$ Schiff I, Tulchinsky D, Ryan KJ. Vaginal absorption of estrone and $17 \beta-$ estradiol. Fertil Steril 1977;28:1063.

${ }^{3}$ Widholm $\mathrm{O}$, Vartianen $\mathrm{E}$. The absorption of conjugated oestrogen and sodium oestrone sulphate from the vagina. Ann Chir Gynaecol 1974;63 : 186

${ }^{4}$ Campbell S, Whitehead MI. Estrogen therapy and the menopausal syndrome. In: Greenblatt RB, Studd JWW, eds. Clinics in obstetrics and gynaecology. Vol 4. No 1. London and Philadelphia: W B Saunders, 1977:31-47.

${ }^{5}$ King RJB, Whitehead MI, Campbell S, Minardi J. Effects of estrogen and progestin treatments on endometria from postmenopausal women. Cancer Res 1979;39:1094-101.

(Accepted 13 October 1981)

Academic Department of Obstetrics and Gynaecology, King's College Hospital Medical School, London SE5 8RX

G I DYER, MIBIOL, MPHIL, biochemist

O YOUNG, SRN, SCM, research nurse

$P$ T TOWNSEND, BSC, MRCOG, research registrar

W P COLLINS, PHD, DSC, professor of reproductive biochemistry

M I WHITEHEAD, MRCOG, lecturer and director of menopause clinic

Chelsea Hospital for Women, London SW3 6LT

J JELOWITZ, cytologist

\section{Paranoid psychosis after abuse of Actifed}

Paranoid psychotic symptoms after the administration of ephedrine have been described.1-3 The symptoms and their course are similar to those of psychosis induced by amphetamine-like drugs. ${ }^{4} 5$ Ephedrine is found in many proprietary decongestant medications. I describe a case of paranoid psychosis after abuse of Actifed, a proprietary decongestant and antihistamine $(5 \mathrm{ml}$ Actifed contains $30 \mathrm{mg}$ pseudoephedrine hydrochloride and $1.25 \mathrm{mg}$ triprolidine hydrochloride).

\section{Case report}

A 27-year-old single male clerical worker presented at the psychiatric outpatient department in May 1981 complaining of acute psychotic symptoms. $\mathrm{He}$ had a six-year history of a bipolar affective disorder and from October 